\title{
Measures of Integrating Media Teaching in Colleges
}

\begin{abstract}
Huang Hui
Hulunbuir University Hulunbuir, Inner Mongolia 021008

huanghui@hlbec.edu.cn

ABSTRACT

In the context of the rapid development of information technology, the integration of media and teaching has become an inevitable trend. Colleges and universities are important places to export talents to the society, and they must pay attention to technology and continuously innovate teaching models. However, as far as most colleges and universities are concerned, the development of internal campus media integration teaching is relatively slow, and there are still many problems, which are also a manifestation of affecting the further development of colleges and universities. This article first elaborates the connotation of media integration and the significance of carrying out media integration teaching in colleges and universities, and then analyzes the problems of media integration teaching in colleges and universities, and finally proposes measures for college media integration teaching. After the 19th National Congress of the Communist Party of China, the Party Central Committee attached great importance to news and public opinion work and the integration and transformation of the media, and introduced relevant policies to promote its development. In the future colleges and universities, the integration of media teaching will also be a development trend. In May 2019, the Ministry of Education launched a pilot project for the construction of media integration in the education system, which has also become a major innovation and breakthrough in college education and teaching. However, as far as most colleges and universities are concerned, the speed of internal campus media integration teaching development is relatively slow. There are still many problems, which are also a manifestation of affecting the further development of universities. This article first explains the connotation of media fusion and the significance of carrying out media fusion teaching in colleges and universities, and then analyzes the problems of media fusion teaching in colleges and universities, and finally puts forward the measures of media fusion teaching in colleges and universities.
\end{abstract}

Keywords: colleges and universities, media integration teaching, meaning, strategy

\section{INTRODUCTION}

The rapid development of Internet information technology has brought tremendous changes to people's lives and work. It also enriches the forms of people's leisure and entertainment, and promotes the development of the entire society. In the traditional society, people pay attention to some magazines and newspapers while leisure, but now people can learn directly through the online platform. At the same time, notice the content of various news media, which is the manifestation of the advantages of the media integration. By realizing media fusion teaching in colleges and universities, a networked learning platform can be built for students. It continuously optimizes traditional teaching methods, enhances students' enthusiasm for learning and the quality of education and teaching.

\section{THE CONNOTATION OF MEDIA INTEGRATION AND THE SIGNIFICANCE OF CARRYING OUT MEDIA INTEGRATION TEACHING IN COLLEGES AND UNIVERSITIES}

\subsection{The connotation of media convergence}

Media convergence has two concepts: narrow and broad. From a narrow perspective, media convergence refers to the fusion of different media forms, resulting in qualitative changes, and forming a new media form, such as blog news. Analyzing media fusion from a broad perspective, it can be seen that it is a combination of all media and related elements. In addition to the fusion of media forms, it also includes the fusion of communication means, media functions and other elements. In short, it effectively combines the 
communication channels of traditional media and emerging media to achieve centralized processing and resource sharing, and then disseminate it to the audience through different platforms. Media integration is mainly a concept of media development in the information age, which is reflected in the integration of technology and business methods [1].

\subsection{The significance of media fusion teaching in colleges and universities}

\subsubsection{It is conducive to establishing the student's dominant position in learning}

The development of media fusion teaching in colleges and universities is an innovation to the traditional single-type teaching. The concrete manifestation of media integration teaching is that colleges and universities can use the advantages of traditional media and existing media to build a platform for students to learn and practice. In this platform, students can study and consolidate relevant knowledge in advance without time and place. This has realized the innovation of the traditional teaching model, has also established the student's dominant position in learning, and has strengthened the student's self-confidence and learning ability in the learning process.

\subsubsection{Conducive to enriching the content and methods of classroom teaching}

Media fusion teaching is not only to build an online learning platform for students, but also to optimize the content and methods of traditional classroom teaching. As far as traditional classroom teaching content is concerned, textbooks are the mainstay, and the teaching methods are also based on a single teacher's explanation. After media integration, teaching content and teaching methods have become diverse. The content of teaching has changed from traditional textbook content to colorful pictures and videos on the Internet, and the teaching method has also changed from single teaching to live teaching, micro-class teaching, MOOC teaching, etc., which enhances the fun of the classroom.

\subsubsection{Conducive to improving the quality of education and teaching in colleges and universities}

In the process of carrying out education and teaching, teachers in traditional colleges and universities only pay attention to whether the course is delivered within a fixed time. Students only need to recite and memorize the key points drawn by the teacher during the mid-term or final exam, and then they can pass the exam. Participate in an internship in the last academic year and conduct a thesis defense to graduate. Under this model, apart from having a graduation certificate, the trained college students do not possess the abilities required by society and enterprises. Obviously, the quality of college education and teaching is worrying. Through the integration of media teaching methods, traditional teaching methods can be changed, so that teachers and students can really pay attention to the learning of theoretical knowledge and the improvement of practical ability in colleges and universities, and cultivate a batch of batches of talents that match the enterprise. This is also An important means to improve the teaching quality and competitiveness of colleges and universities [2].

\section{THE PROBLEMS EXISTING IN UNIVERSITY MEDIA INTEGRATION TEACHING}

It can be seen from the technical characteristics and manifestations that campus media can be divided into emerging, traditional and auxiliary media. Among them, traditional media refers to broadcasting, newspapers, magazines, etc., and new media is mainly based on the Internet and mobile phone networks. Auxiliary media are electronic display screens, posters, exhibition rooms, etc. By investigating the education and teaching situation of various universities, we can see that the effect of media integration is not good. And most of them are in the shallow integration stage, and have not played the advantages of media integration teaching, which are specifically reflected in the following points:

\subsection{The concept of traditional exam-oriented education for college teachers is deeply rooted}

For a long time, our country has been under the background of exam-oriented education, that is, taking exams as the ultimate goal to educate students, only requires students to get high scores in the exams. It doesn't pay much attention to the cultivation of students' learning ability and literacy in the whole learning process. This also makes the talents cultivated in traditional society unable to adapt to the needs of enterprises. Colleges and universities are places to transport talents for future enterprises, and teachers' traditional test-oriented education concepts will inevitably affect the development of college media integration teaching. For example, some teachers incorporate some new types of media in the teaching process, but they still focus on the teacher's explanations, and do not really give full play to the advantages of media-integrated teaching, which also affects the quality of the entire teaching.

\subsection{The mode of campus media and media integration teaching is relatively single}

There are many modes of media integration teaching, such as cooperation between universities and some 
newspapers and magazines to carry out corresponding practical activities. Either through media integration, building a platform for online learning, or incorporating some new media teaching methods into the classroom teaching process. However, in colleges and universities, the common media integration is mainly based on broadcasting and mobile phones, and there are only multimedia devices in the classroom. This has also led to many college teachers unable to exert better results when using media fusion teaching. For example, most teachers still use a single multimedia teaching when teaching, without integrating micro-class teaching, live teaching, and distance teaching.

\subsection{College teachers lack certain information technology literacy}

As far as teachers in colleges and universities are concerned, they have relatively high academic qualifications and their own professionalism is relatively strong, but there are deficiencies in information technology. For example, some old teachers in colleges and universities are relatively old and have an inherent teaching mode. In the context of media convergence, it is difficult to seize the advantages, to innovate their own teaching model, and the speed of learning information technology is relatively slow. Like some young teachers, most of their energy is focused on scientific research, and teaching is also following the pace of old teachers, lacking innovation, and the atmosphere of media integration teaching in the entire university is poor [3].

\section{MEASURES TO INTEGRATE MEDIA TEACHING IN COLLEGES AND UNIVERSITIES}

\subsection{Increase funding to build a platform for media-integrated teaching}

There is relatively little media integration in colleges and universities, and most of them are mainly based on students' mobile phones and school broadcasts, and there is no platform for media integration teaching based on some advanced technologies or methods. When propagating campus events, the main focus is on broadcasting, which is not in line with the needs of the development of the times. Therefore, colleges and universities must increase funds, actively study the actual status of the development of colleges and universities, and build a platform for media-integrated teaching. First, we should build a school's own media, such as the school's WeChat official account, Weibo, etc. Regularly publicize the curriculum settings, education programs and practical results of each major of the school in this media platform to achieve the publicity of the school's majors. The second is to increase capital investment to provide teachers of various subjects with a platform for media-integrated teaching, where teachers can regularly upload prepared preparatory lesson plans, classroom lesson plans, and consolidation lesson plans. Students can log on to the platform to preview, study and review independently, creating a good space for students to study independently. Finally, as far as current colleges and universities are concerned, they are constantly expanding their enrollment, and the employment rate of colleges and universities is their competitiveness [4]. Through continuous reform of teaching and the promotion of the atmosphere of media fusion teaching, teachers can increase the enthusiasm of using media fusion in the teaching process and create a good atmosphere of media fusion teaching.

\subsection{Optimize the curriculum and establish a general + professional + technical curriculum system}

In the context of media convergence, the content of traditional education and teaching should also be changed. Because media integration can not only be innovative in teaching, it will be demonstrated in all walks of life in society, take journalism and communication as an example. Under the background of the rapid development of information technology, the news media industry of communication has also changed, such as the integration of new media, which requires universities to optimize the traditional classroom system. For example, the curriculum system for college journalism and communication students can be divided into general, professional, and technical. General education is the basic course, including college English, mass communication, multimedia information processing, network design and production, etc. In this part, compared with the past, courses related to Herong Media have been added [5]. Professional knowledge includes news courses, industry courses, technical courses, and marketing courses. In the professional courses, it is necessary to increase the media news reports related to Herong Media and the learning of media digital technology. The technology-based curriculum system is mainly to cooperate with schools and enterprises, combine the practical activities of the media to carry out news broadcasts, and enhance the comprehensive practical ability of college students. In short, under the background of media convergence, all walks of life will undergo changes. In response to this change, the curriculum systems of all majors in various universities should be optimized and improved.

\subsection{Optimize classroom teaching mode and implement media integration teaching}

As can be seen from the connotation of media convergence above, media convergence refers to the use of emerging media's communication channels and the advantages of traditional media to achieve resource 
sharing. Through different platforms, deliver relevant content to the audience. In the process of teaching in colleges and universities, teaching can also be carried out through media integration, which continuously expands the time and space of previous education and teaching, and implements the learning ability and quality of college students.

\subsubsection{Build a platform for course preview in colleges and universities}

Under the background of media convergence, as a university, it is necessary to actively adapt to the needs of the development of the times, increase investment in school hardware and software equipment, and establish an online learning platform. In this platform, modules of various majors, grades, and disciplines are set up. Relevant teachers can click on this module and upload relevant content for preview. For example, as far as current college students are concerned, the study time per day is very short, and there is ample spare time. In order to improve the ability of students to learn independently, teachers can make preview lesson plans in advance and upload them to a fixed platform. Students click on the platform to learn and answer related questions in the preparatory session. Teachers watch the results of students' preview in the background, and if possible, can use big data to count the results of students' learning, and continuously optimize the content and methods of classroom teaching to achieve targeted education.

\subsubsection{Use micro-classes, multimedia and other media integration methods to carry out course teaching}

As we all know, the study of theoretical knowledge is very boring and tedious, which requires teachers to actively learn some new technologies and methods of media integration. Make full use of it in the classroom to enhance the interest of the classroom and attract students to actively participate. At present, there are many methods of media integration teaching, such as micro-class teaching, flipped classroom teaching, MOOC teaching, multimedia teaching and so on. Multimedia teaching is a relatively common means of media integration in colleges and universities, and flipped classroom teaching is to use the advantages of advanced media. Realize the flip of the roles of teachers and students, and make full use of the time inside and outside the classroom. MOOC teaching, also known as MOOC, is a large-scale open online course based on open pedagogy based on connectivity theory and networked learning. Teachers need to adopt a reasonable strategy of media integration based on the actual situation of the school and the class.

\subsubsection{Course review and consolidation based on the built platform}

In addition to making full use of class time, college teachers should also use media integration to build a platform for students to communicate after class, such as WeChat groups and QQ groups. In the group, allow students to discuss daily life, or discuss problems in the learning process. Teachers set up review and consolidate content according to the corresponding questions raised by students, upload them to a fixed platform, and students can learn and consolidate in their spare time [6].

\subsection{Build a school-enterprise cooperation platform based on media integration and implement application-oriented talents}

School-enterprise cooperation is an important means for colleges and universities to cultivate more outstanding talents for the society. In the context of media convergence, colleges and universities can build a platform for cooperation with schools and enterprises, and this platform should contain several contents. The content of the first school-enterprise cooperation, such as the combination of basic knowledge and corporate practice, regularly displays the results of these content cooperation on the platform to achieve the purpose of school-enterprise publicity. The second is to establish a specialized knowledge learning module for school-enterprise cooperation, in which the combination of theory and practice is the main focus. If students want to practice a certain aspect, they can first learn the theory, click to make an appointment, and the company will arrange practical activities for students to go for internships. Third, use the advantages of corporate media integration, increase publicity, inject more funds or help for school-enterprise cooperation, and lay the foundation for the implementation of applied talents.

\subsection{Optimize the talent evaluation model in universities}

Traditional colleges and universities evaluate students mainly based on their daily attendance rate, test scores, internships and thesis defense. As long as students attend classes on time, don't drop subjects, and complete the thesis, they can graduate. Such an evaluation model is actually lacking in science. In the context of media fusion teaching, students' learning can be recorded and aggregated into comprehensive data. Therefore, it is necessary to optimize the traditional talent evaluation mode of colleges and universities. The evaluation is divided into students' daily preview time + classroom interaction performance + corporate practice performance + ability + paper, and the proportion occupied by each proportion is reasonably allocated to 
give play to the role of talent evaluation in college media integration teaching.

\subsection{Incorporate multiple methods to enhance the ability of college teachers to integrate media teaching}

Media-integrated teaching requires not only the support of college platforms and materials, but also the cooperation of college teachers. Through the above analysis, it is understood that college teachers lack the ability of media-integrated teaching, which also hinders the innovation of education and teaching. Therefore, it is necessary to build an excellent team within the colleges and universities through training and joint discussions with colleges and universities, and create a good atmosphere of education and teaching innovation. First of all, in colleges and universities, there should be regular training on the methods of media fusion teaching and the methods of using information technology to provide guarantee for the realization of media fusion teaching. Secondly, it is necessary to strengthen the teaching and discussion activities among teachers of other colleges and universities of the same specialty, which can learn from each other and grow together through lectures and competitions.

\section{CONCLUSION}

In summary, under the background of media integration, it is possible to innovate in education and teaching in colleges and universities. However, if you want to truly implement media-integrated teaching, you still need the support of universities in many aspects. For example, building a platform for online course learning within the school, optimizing the traditional curriculum system and evaluation methods, and continuously improving teachers' ability of media fusion teaching, etc., to build a good atmosphere for college media fusion teaching.

\section{REFERENCES}

[1] Liu Lijie, Li Fan. The reform and innovation of the teaching methods of ideological and political courses in colleges and universities from the perspective of media integration[J]. Education Modernization, 2020, 7(51): 50-53.

[2] Han Jianhua, Chen Xin. Thoughts on the teaching development of media college teachers in the era of media integration $[\mathrm{J}]$. China Radio and Television Journal, 2020, \{4\}(02): 48-53.

[3] Yang Yeju. The iterative principle of the teaching art of college ideological and political teachers under the concept of media integration[J]. Journal of Chengdu Aviation Vocational and Technical College, 2019, 35(04): 1-3+7.
[4] Wei Xuan. A Probe into the Blended Teaching of "Media English" under the Background of Media Convergence[J]. Journal of Beijing City University, 2021, \{4\}(02): 85-88+100.

[5] Yuan Xingmei, Yang Jingjing, Li Zihan. Application of media integration to innovate the construction of college teachers' ethics and style [J]. China Adult Education, 2020, \{4\}(22): 86-88.

[6] Liu Pan, Xiao Yu, Wu Xing, Long Yue. Problems and suggestions in the multi-media integration teaching model $[\mathrm{J}]$. Education Teaching Forum, 2020, \{4\}(43): 319-320. 